\title{
Correlation of concentrations of selected trace elements with Gleason grade of prostate tissues
}

\author{
A. Banas • W. M. Kwiatek • K. Banas • \\ M. Gajda $\cdot$ B. Pawlicki $\cdot$ T. Cichocki
}

Received: 27 January 2010/ Accepted: 12 May 2010/Published online: 25 May 2010

(C) The Author(s) 2010. This article is published with open access at Springerlink.com

\begin{abstract}
The causes of prostate cancer are still obscure but some evidence indicates that there is a close connection between several trace elements and processes which may lead to malignant cells. In our study the microbeam synchrotron radiation X-ray fluorescence emission (microSRIXE) technique was applied for quantitative analysis of selected elements. For the first time, we correlate the concentrations of $\mathrm{Mn}, \mathrm{Fe}, \mathrm{Cu}$, and $\mathrm{Zn}$ with the clinical stage of the prostate cancer at the time of operation (described by Gleason grade). Serial sections of prostate tissues were collected from patients undergoing radical prostatectomy. One section, stained with hematoxylin and eosin, was prepared for histopathological analysis; a second, adjacent unstained section was used in micro-SRIXE experiments. All experiments were performed at beamline L at HASYLAB, DESY, Germany. Our results seem to be valuable in light of the determination of the changes in the
\end{abstract}

A. Banas · W. M. Kwiatek · K. Banas

Institute of Nuclear Physics,

Polish Academy of Sciences,

Radzikowskiego 152, 31-342 Kraków, Poland

A. Banas $(\bowtie) \cdot$ K. Banas

Singapore Synchrotron Light Source (SSLS),

National University of Singapore,

5 Research Link, Singapore 117603, Singapore

e-mail: slsba@nus.edu.sg

M. Gajda · T. Cichocki

Department of Histology, Collegium Medicum,

Jagiellonian University, Kopernika 7,

31-034 Kraków, Poland

B. Pawlicki

Gabriel Narutowicz Hospital, Prądnicka 37,

31-202 Kraków, Poland concentrations of trace elements as a potential diagnostic marker and their etiological involvement in the different stages of prostate diseases.

Keywords Trace elements - Prostate cancer . Gleason grade $\cdot$ Microbeam synchrotron radiation $\mathrm{X}$-ray fluorescence emission

\section{Introduction}

The prostate is a small, squishy gland the size of a walnut that is situated under the bladder and in front of the rectum. Male hormones are responsible for growth of the prostate gland in the fetus. The prostate gland grows until a man reaches adulthood and then stays about the same size as long as male hormones are produced [1].

Prostate cancer is the most frequently diagnosed cancer in men and is the second leading cause of cancer death [2]. Intensified screening efforts in recent years and the use of prostate-specific antigen as a marker of disease have resulted in increased diagnosis of early-stage disease. Although researchers still do not know exactly what causes prostate cancer, they have identified some factors that increase the risk of getting it: age, family history, ethnicity, diet, and obesity [1-3]. Prostate cancer occurs when cells in the prostate gland grow and multiply uncontrollably. The nodular tumor mass invades the surrounding tissues and eventually spreads to the lymph nodes, skeletal bones, and other regions of the body. Although several cell types are found in the prostate, over $99 \%$ of prostate cancers develop from the glandular cells and are therefore described as adenocarcinoma [3, 4].

Over the past 15 years, more detailed descriptions of cancers have been given by pathologists; prostate tissues 
were classified using a new tool-Gleason grade [5-7]. This system is based on the architectural patterns of cancer glands observed by the pathologist under the microscope (Fig. 1). Whether or not the cancer is likely to grow slowly or very quickly depends on, according to Gleason grading, how closely the cells of the cancer resemble normal cells. Those cells that look like normal glandular tissue with some cancer cells in the lining are termed as "well-differentiated cancers." They have a low Gleason grade ( 1 or 2 ), grow slowly, and take a long time to become clinically significant.

Cells that appear very little like normal glands and more like sheets of packed cancer cells are termed "poorly differentiated cancers" (Gleason grade 4 or 5); these tumors are very aggressive and most treatments have poor results. Finally, cells which form multiple small glandular spaces are in the middle of the Gleason grade scale and are called "moderately well differentiated cancers" (Gleason grade 3 ).

Undoubtedly, Gleason grading provides much valuable information in terms of prostate cancer classification, but a limitation of this technique is the disparity between tissue architecture and its biochemical status. Understanding what exactly happens when prostate cancer begins to grow seems to be very important; it may also help in selection of reliable treatment options and it could help save many men's lives.

There is still a need for additional markers which could increase the sensitivity and specificity of prostate cancer detection and also aid in the selection of the therapy for the treatment of disease. Some authorities in urology have suggested that all new prognostic markers should be evaluated in conjunction with Gleason grade [8].

For many years studies of the concentration of trace elements have played an important role in field of better understanding of different processes occurring in cells. Instability (overabundance or deficiency) in the composition of trace metals that are recognized to be essential to normal human homeostasis and the accumulation of potentially toxic or nonessential trace metals may lead to different diseases. It was also proven that some trace elements play a critical role in cancer biology; however, there is still a serious lack of information concerning their function in initiation, promotion, and inhibition of carcinogenic processes in prostate glands [9-15]. Thus, there is a real need for analysis of trace elements in cancerous and noncancerous human tissues to examine the relationship between cancer and these elements. Detailed in situ studies are necessary if the role of metal accumulation in the structural and functional changes produced by the disease are to be understood.

Of the many methods suitable for detection of the concentration of elements in biological tissues, the most preferred are multielemental highly sensitive analytical techniques such as synchrotron radiation X-ray fluorescence emission (SRIXE). In our work we used synchrotron radiation to detect and locate selected trace elements in postoperative samples of prostate tissues at cellular and subcellular (especially in the case of cancerous cells) resolution. Fluorescence spectra provide a fast and sensitive means of detecting anomalous metal concentrations in a tissue section, and because of a high-intensity focused beam it is possible to locate the concentrations of selected elements within a few microns. In our studies we focused mainly on analysis of the trace elements $\mathrm{Mn}, \mathrm{Fe}, \mathrm{Cu}$, and $\mathrm{Zn}$ owing to their vital roles in the biochemistry of all living cells. Their concentrations were determined in cancerous prostate tissues at different stages of disease described by Gleason grade (2, 3, and 4). Additionally, healthy and hyperplastic prostate tissues were analyzed. Our studies were carried out to understand the effects of altered homeostasis of selected elements in the origination of prostate cancer.

\section{Materials and methods}

\section{Samples}

All materials (prostate glands) were obtained during radical prostatectomies from 12 patients (patients' age 56-72 years, mean age 61) at the Department of Urology, Szpital Miejski Specjalistyczny im. Gabriela Narutowicza, Kraków, Poland.

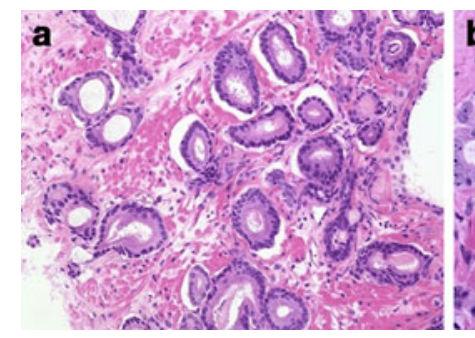

Fig. 1 Hematoxylin- and eosin-stained prostate cancer tissue of Gleason grades 2-4, exhibiting examples of malignant glands that were used to acquire microbeam synchrotron radiation $\mathrm{X}$-ray fluorescence emission (micro-SRIXE) spectra: a Gleason grade 2, b Gleason grade 3 , c Gleason grade 4 
The sample preparation was performed in a controlled environment to eliminate or at least minimize any contamination effects. All samples were prepared in the same way. First, material dedicated for analysis was frozen in liquid nitrogen to stop all living processes occurring in cells and hence to avoid any alteration in the concentrations of all elements. Then, all specimens were cut into $14-\mu \mathrm{m}$ slices with the use of a cryomicrotome; for microSRIXE experiments over 100 samples were prepared, and each slice was mounted on Mylar foil and air-dried. For every experimental sample, an adjacent section (of the same thickness) was placed on a microscope glass, and was then stained with hematoxylin and eosin (H\&E) dye.

An experienced histopathologist fully characterized H\&E-stained sections microscopically by dividing them into noncancerous (healthy and hyperplasic prostate tissues) and cancerous groups; additionally, the Gleason grade was assigned to areas of malignancy. We obtained the parts of prostate glands classified as healthy, hyperplastic, Gleason grade 3 and 4 from two patients and the parts classified as Gleason grade 2 from four patients. The histopathologist identified areas of abnormal cell growth and found the areas of the cancer; its appearance was compared with the Gleason scale system to determine where it falls on a scale of 1-5. All samples used in this work were analyzed by the same person.

From histopathology studies certain areas were selected for further micro-SRIXE studies and were used as landmarks to position the microbeam on the lesions of the unstained adjacent section. Careful analysis of selected samples was made using an Olympus BX-50 microscope. We did not observe any damage in sample patterns, which would be caused by the Leidenfrost effect [16]. Examples of H\&E-stained sections analyzed during the experiments are presented in Fig. 1.

\section{Measurements}

The spectra were collected at beamline L at HASYLAB, DESY (Germany), using the synchrotron X-ray fluorescence microprobe. The photon flux delivered by the bending magnet at HASYLAB (positron energy $4.45 \mathrm{GeV}$, storage ring current $140 \mathrm{~mA}$, and magnetic field $1.2182 \mathrm{~T}$ ) is $5 \times 10^{13}$ photons $/ \mathrm{mrad}^{2} / 0.1 \%$ bandwidth at $10 \mathrm{keV}$. The microprobe setup is a powerful instrument for simultaneous multielement trace analysis of microsamples (http://www. hasylab.de) [17-19].

The micro-SRIXE observation was conducted in air without pretreatment and staining of samples. Using this highly brilliant synchrotron source at HASYLAB, one can routinely detect elements with atomic numbers between 13 and 92 with minimum detection limits down to $0.1 \mathrm{pg} / \mu \mathrm{g}$. The white beam of a bending magnet source was monochromatized by a double-multilayer monochromator with bandpass $\Delta E / E \cong 2 \%$. The photon flux at the sample with a $\mathrm{Si}(111)$ monochromator was $9 \times 10^{9}$ photons $/ \mathrm{mm}^{2} / 0.01 \%$ bandwidth at $10 \mathrm{keV}$. The beam was focused by a polycapillary half lens (X-ray Optical Systems, focal distance $4.8 \mathrm{~mm}$ and transmission of $30 \%$ ) and its size on the sample was approximately $15 \mu \mathrm{m}$ (in diameter), which is of the order of a cell diameter. For our study the energy was set to $17 \mathrm{keV}$. By using this energy, we could collect fluorescence spectra with very well determined peaks for $\mathrm{K}_{\alpha}$ lines of elements with atomic number between 15 and 38 . Figure 2 depicts an example spectrum collected from a healthy prostate sample.

All experiments were performed on individual samples placed on 2.5- $\mu \mathrm{m}$ Mylar foil. This foil is strong enough to support the tissue, and it can also withstand the focused beam. Additionally, what is the most important aspect for our analysis, measurements made on this foil gave a clean background in terms of the fluorescence signal of the elements of interest.

During analyses the samples were fixed on a remotecontrolled stage equipped with high-precision stepping motors allowing for micrometric movements in $x y z$ space (reproducible positioning of about $0.5 \mu \mathrm{m}$ ). The samples on the special holder were positioned at an angle of $45^{\circ}$ with respect to the incoming beam, just in front of the polycapillary (Fig. 3).

$\mathrm{X}$-ray fluorescence was detected by use of a conventional high-purity Ge X-ray detector (with an energy resolution of $120 \mathrm{eV}$ at $5.89 \mathrm{keV}$ ) positioned at $90^{\circ}$ to the incoming linearly polarized X-ray beam and placed in the storage ring plane to minimize the intensity of the scattering X-rays. The beryllium window of the detector was $8 \mu \mathrm{m}$ thick. The air path between the samples and the detector was set to a few millimeters; it was set after several tests to optimize the experimental conditions. The

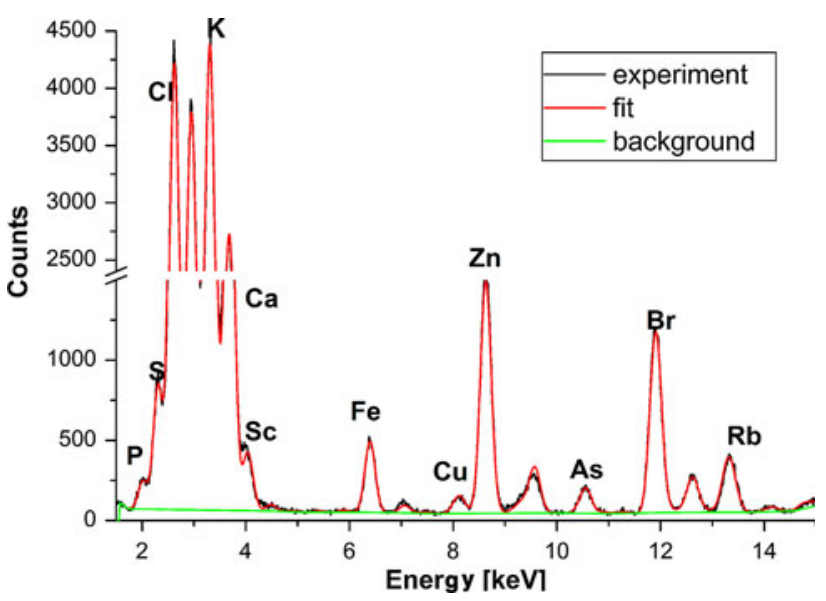

Fig. 2 Micro-SRIXE spectrum collected from healthy prostate tissue 


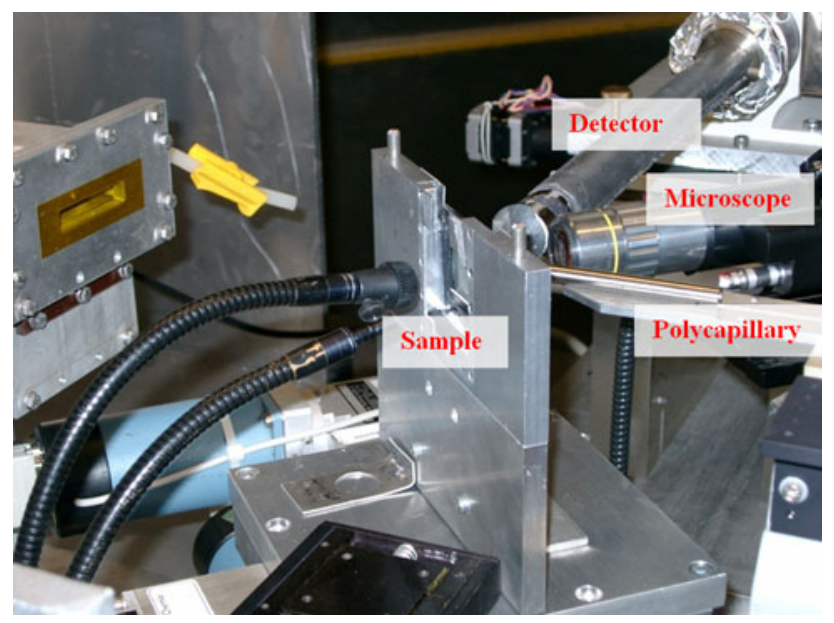

Fig. 3 The experimental table showing the sample holder arrangement at beamline $\mathrm{L}$ at HASYLAB

acquisition time of a single spectrum was $300 \mathrm{~s}$ in order to obtain reliable spectra with good signal-to-noise ratio. Only areas previously selected by the histopathologist were analyzed. On the same type of cell packaging, single points were measured with a distance of around 15-20 $\mu \mathrm{m}$ between them. If there were any significant discrepancies between the spectra collected for these points, additional examinations were performed by the histopathologist.

The spectra collected were deconvolved by using the AXIL program [20]. The evaluation of energy-dispersive X-ray spectra by means of AXIL was achieved by fitting the measured spectra with suitable mathematical functions, using a nonlinear least-squares strategy. A special model including information about the Gaussian line shape centered around the proper energy, positions of the lines, their relative amplitudes, the distance between the $\mathrm{K}_{\alpha}$ and $\mathrm{K}_{\beta}$ lines, the shape of the background, etc. was created prior to analysis of the actual spectrum using the X-ray library available in the software. In the analysis presented, the smooth filter background was chosen. The smooth filter procedure is based on the removal of rapidly varying structures in a spectrum by comparing the channel content $y_{i}$ with the channel content of its neighbors. For each spectrum the background was subtracted. Additionally, all spectra were normalized to the value of the incident photon flux.

For dry mass concentrations of the elements in the samples analyzed (expressed in micrograms per gram) two gelatine homemade standards were prepared [21]. Standard MULT I consisted of a mixture of nitrates of metals such as $\mathrm{Ca}, \mathrm{V}, \mathrm{Fe}, \mathrm{Zn}, \mathrm{As}, \mathrm{Pb}, \mathrm{Sr}, \mathrm{Zr}$, Mo, and $\mathrm{Cd}$, whereas MULT II included $\mathrm{K}, \mathrm{V}, \mathrm{Mn}, \mathrm{Fe}, \mathrm{Zn}, \mathrm{Hg}, \mathrm{Pb}, \mathrm{Sr}, \mathrm{Zr}$, and $\mathrm{Mo}$. The metal concentrations in those standards were $10 \mu \mathrm{g} / \mathrm{g}$, which was additionally confirmed by atomic absorption spectroscopy.
For calculation of the concentrations for $\mathrm{Mn}, \mathrm{Fe}, \mathrm{Cu}$, and $\mathrm{Zn}$ "the external standard method" was used [22].

\section{Results and discussion}

Statistical analysis

Statistical analysis and graphic presentation of the data were done with the $\mathrm{R}$ platform (version 2.10) [23]. To check the normality of the distribution of the concentrations obtained and to select the correct method for further analysis of the data collected, the Shapiro-Wilk test was performed. This test is tailored to access the goodness of the fit to the normal distribution and is considered a better choice than Kolmogorov-Smirnof and Lilliefors tests. According to the results of this test, all distributions of the concentrations of the selected elements were not normal (with $P<0.05$ ), which is understandable in the case of analysis of biological samples because several factors may contribute to the concentration range of the results, such as differences in diet, hormonal status, age, genetics, and drug administration.

Over 300 spectra collected during the experiments from different samples were taken into account in the statistical analysis. The average number of spectra for each group of prostate tissues (healthy, hyperplastic, Gleason grades 2-4) was 60. For every element under consideration, basic descriptive statistical parameters were calculated (median, minimum and maximum, skewness, and curtosis values). Median values were chosen since the concentration distributions of the elements were asymmetric. Almost all the distributions of elemental content within the different groups of specimens are positively skewed, which is typical for biological media [24].

Violin plots [25] were selected to present the results of the statistical analysis. They are similar to box plots, except that they also show the probability density of the data at different values. As shown in Figs. 4, 5, 6, and 7, the violin plot includes a box plot with two slight modifications. First, a circle replaces the median line, which facilitates quick comparisons when viewing multiple groups. Second, outside points which are traditionally classified as outliers are not identified by individual symbols. The kernel density estimation overlaid on the box plot supplements traditional statistics by graphically showing the distributional characteristics of data.

For the concentration distributions of $\mathrm{Mn}, \mathrm{Cu}$, and $\mathrm{Zn}$ we observed a wide spread of values for the Gleason grade 2 group (Figs. 4, 6, 7), whereas for the other groups this spread is narrower (except for $\mathrm{Zn}$ in hyperplastic tissue); this may be connected with the fact that the Gleason grade 2 group is represented by material taken from four different 
Fig. 4 Overview of statistical analysis of Mn concentration in tissue specimens

Fig. 5 Overview of statistical analysis of $\mathrm{Fe}$ concentration in tissue specimens

Fig. 6 Overview of statistical analysis of $\mathrm{Cu}$ concentration in tissue specimens
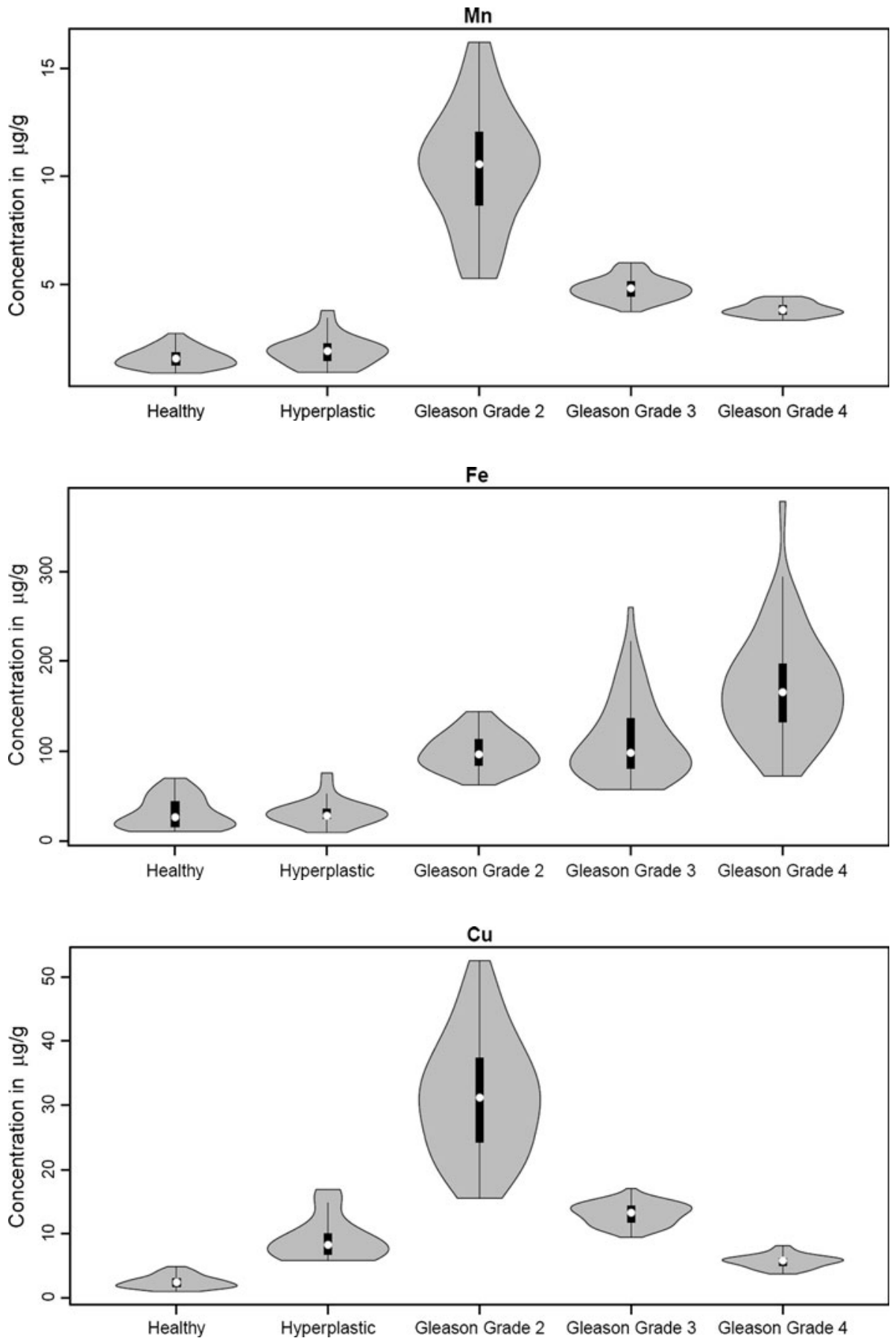

patients, but it may also indicate dynamic metabolism of these elements in this group. For the $\mathrm{Fe}$ concentration distribution, a wide spectrum of values is observed for Gleason grade 3 and 4 groups (Fig. 5).

\section{Manganese}

Manganese is a crucial trace element found in all tissues, and it is required for normal amino acid, lipid, protein, and carbohydrate metabolism; it is also necessary in reproduction, including sex hormone production, and the functioning of the mammary glands and in the nourishment of nerve and brain cells. It is vital to thiamine (vitamin $\mathrm{B}_{1}$ ) metabolism and tocopherol (vitamin E) utilization [26, 27]. Manganese takes part directly in the defense of red blood cells, in the metabolism of $\mathrm{Fe}$, and in the synthesis of cholesterol in the membranes and oligosaccharides.

During our studies no significant differences between concentrations (median values) for $\mathrm{Mn}$ in healthy and hyperlastic prostate tissue were observed (Fig. 4). This may 
Fig. 7 Overview of statistical analysis of $\mathrm{Zn}$ concentration in tissue specimens

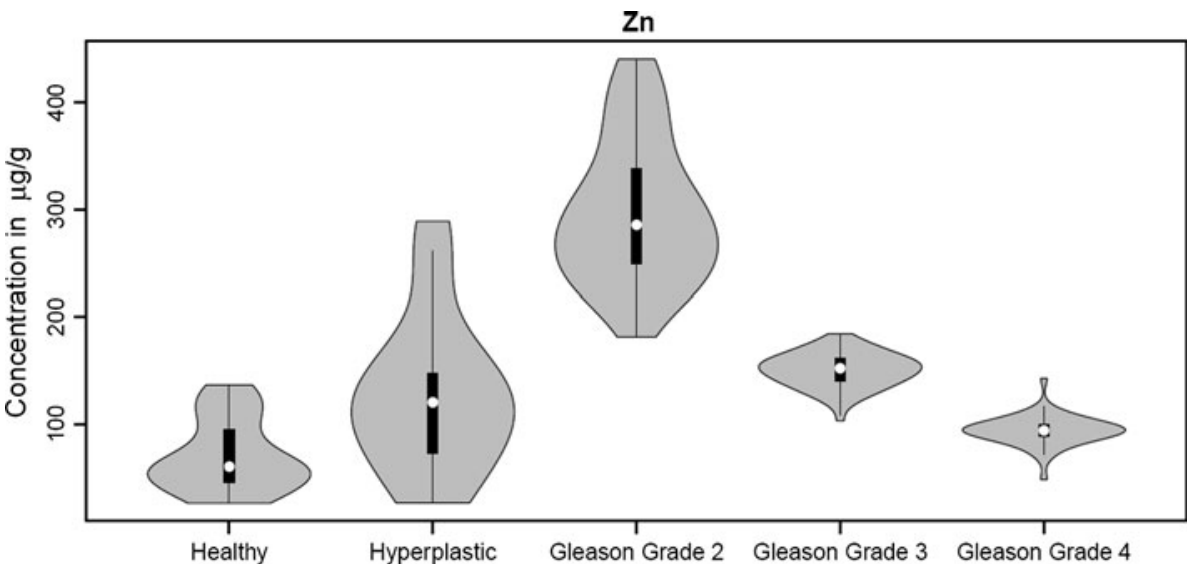

be linked to very similar metabolism in cells from these two groups. But the situation changes dramatically for one of the first prostate cancer stages, in our analysis designated as Gleason grade 2. For these tissues the highest concentration of Mn was noted, almost 10 times higher than for healthy and hyperplastic groups. This fact may reflect the role which $\mathrm{Mn}$ plays in cancerogenesis. Although $\mathrm{Mn}$ deficiency is extremely rare in humans, toxicity of $\mathrm{Mn}$ is more prevalent [28]. Manganese as one of the transition metals is able to catalyze the Fenton reaction, under certain conditions, when these metal ions are not bound to proteins or chelators. A Fenton-like reaction may take place and cause site-specific accumulation of free radicals and initiate biomolecular damage processes. Free radicals can cause tissue damage by reacting with polyunsaturated fatty acids in cellular membranes, nucleotides in DNA, and critical sulfhydryl bonds in proteins. There is some evidence that free-radical damage contributes to the origination of many chronic health problems, such as emphysema, cardiovascular and inflammatory diseases, cataracts, and cancer [29]. It seems that the elevated level of Mn observed in the Gleason grade 2 group may enhance prostatic carcinogenesis.

On the other hand, Mn plays a significant role in the free-radical defense system as manganese superoxide dismutase, which protects mitochondria, the endothelial cells, and red blood cells from the damage caused by superoxide radicals. The decreasing amount of Mn observed for more advanced stages of cancer (Gleason grades 3 and 4) compared with the Gleason 2 group is probably connected with loss in activity of manganese superoxide dismutase [30].

\section{Iron}

Iron is essential for the normal physiological functions in humans, as an integral part of many proteins and enzymes. It also plays a vital role in the regulation of cell growth and in cell differentiation [31, 32]. Physiological maintenance of relatively constant levels of $\mathrm{Fe}$ is crucial, since both $\mathrm{Fe}$ deficiency and Fe overload are harmful, and can contribute to disease development in several ways. Iron overload is associated with several chronic diseases, such as heart disease [33, 34], cancer [11, 12, 14, 15, 35], diabetes [36], and defective immune regulatory control [37]. Iron can both cause and promote cancer. Any unregulated level of $\mathrm{Fe}^{2+}$ has the potential to catalyze and generate hydroxyl radicals from superoxide and hydrogen peroxide via the Fenton reaction. The highly reactive hydroxyl radicals subsequently cause lipid peroxidation and degradation of other macromolecules, leading to cell damage or death [38-40]. Iron also contributes to disease development by functioning as a nutrient for microbial and neoplastic cells $[41,42]$. Iron promotes inflammation and an increase in cancer cell growth [43]. The important role of $\mathrm{Fe}$ in stimulating angiogenesis has also been suggested [44].

In the present study, higher levels of Fe were observed in the malignant prostate tissues relative to the noncancerous tissues (healthy and hyperplastic groups). It is worth noting that the concentrations for this element increased with advancement of the cancer stage: about 3 times for Gleason grades 2 and 3. The highest level was observed for the Gleason grade 4 group (almost 6 times higher compared with healthy prostate tissue), which may prove that despite its metabolic essentiality, Fe is somehow involved in cancerogenesis. There is a hypothesis that high body Fe stores increase the risk of cancer in men [45].

\section{Copper}

In normal conditions $\mathrm{Cu}$ is found in all living cells. This element is fundamental for a wide range of biochemical processes, but it is also a potentially toxic substance.

Elevated concentrations of $\mathrm{Cu}$ (in comparison with healthy tissues) observed not only in cancerous tissues (Gleason grades 2, 3, and 4) but also in hyperplastic ones (Fig. 6) may indicate that this element is linked with some 
dysfunction occurring in prostate cells. This dysfunction is strongly stressed for the Gleason grade 2 group, where the highest concentration-about 15 times higher than in healthy prostate-is observed. Copper is one of the promoters of the Fenton reaction; changing its oxidation state, it can cause harmful effects on the functioning of the cell through the generation of highly reactive oxygen species, which produce hydroxyl radicals that adversely modify proteins, lipids, and nucleic acids [46, 47]. Cell damage caused by oxygen free radicals may signify the prominent role of $\mathrm{Cu}$ in the first stage of neoplasm formation (Gleason grade 2).

Copper is also believed to be the switcher that turns on angiogenesis in tumor cells. It has been observed that abnormally high serum $\mathrm{Cu}$ levels are found in patients with many types of progressive tumors [48-50]. Maybe the highest level of $\mathrm{Cu}$ observed in the Gleason grade 2 group is also connected with the production of new blood vessels, which are used for "feeding" the tumors.

Like $\mathrm{Mn}, \mathrm{Cu}$ has also been recognized to play an important role as a cofactor of superoxide dismutase [38]. According to our analysis, the concentration of $\mathrm{Cu}$ is decreased with more advanced stage of prostate cancer; maybe this is linked to a reduction in the defensive capability of cells.

\section{Zinc}

Zinc is a vital element in the nutrition of humans, animals, and plants. Although most experimental data have demonstrated the adverse effects of $\mathrm{Zn}$ deficiency on human and animal health, there is still evidence to support the hypothesis that $\mathrm{Zn}$ toxicity can also result in deleterious health effects [51-53]. Conflicting views have been expressed regarding the role of $\mathrm{Zn}$ in carcinogenesis. Some studies $[54,55]$ emphasize the fact that $\mathrm{Zn}$ deficiency causes cancers, whereas others $[53,56,57]$ highlight that $\mathrm{Zn}$ is involved in tumor growth and development of neoplastic transformation. These conflicting observations suggest that the role of $\mathrm{Zn}$ in different organs may be different. According to works by Ho and Song [58] and Sapota et al. [59], the prostate contains the highest concentration of $\mathrm{Zn}$ of all the soft tissues; in prostate cancer this level decreases rapidly. Our studies reported earlier [15] showed that prostate cancer tissues contain elevated concentrations of Zn when compared with normal (healthy) prostate tissues.

In our present studies we still try to sustain the hypothesis mentioned earlier about the influence of $\mathrm{Zn}$ on prostate cancer. The highest $\mathrm{Zn}$ concentration observed in Gleason grade 2 tissue (almost 6 times higher compared with healthy prostate tissue) illustrates the fact that every highly proliferating cell system is dependent on sufficient availability of $\mathrm{Zn} \mathrm{[60].}$
Zinc is also as an essential element for the immune system $[61,62]$. Its concentration has to be balanced for the proper functioning of the immune system since both an increased and a decreased amount of this element result in a disturbed immune function. Alterations in immune function increase the risk of several diseases, including cancer.

The elevated concentration of $\mathrm{Zn}$ possibly leads to the development of various disorders in the prostate gland. A higher concentration of $\mathrm{Zn}$ in hyperplastic prostate tissues compared with healthy ones was also observed by Sapota et al. [59]. In our analysis we noted an increase in the concentration also for Gleason grade 2, 3, and 4 groups, but it is worth mentioning that the concentration for this element gradually decreases for more advanced Gleason grades; the same trends were observed for $\mathrm{Mn}$ and $\mathrm{Cu}$ concentrations.

Summary of the statistical results

To validate our observations and confirm their statistical importance, the Wilcoxon signed rank test for unpaired samples was used. A summary of the results is presented in Table 1. The $P$ values are the products of nonparametric comparison between the groups representing the healthy and diseased tissue samples. $P$ values lower than the cutoff point of 0.05 indicate that the two groups differ significantly with respect to the property that was used for the comparison. The results obtained indicate that in the most of the cases the selected elements significantly differentiate the groups analyzed; a weaker dependence is observed for $\mathrm{Zn}$ in distinguishing between hyperplastic-Gleason grade 3 and hyperplastic-Gleason grade 4 groups.

Neither Fe nor Mn can be used to discriminate between healthy and hyperplastic prostate tissue; similarly, $\mathrm{Fe}$ cannot be a good indicator for differences between Gleason grade 2 and 3 groups.

\section{Conclusions}

Our studies were undertaken to establish the variations in trace element concentrations between healthy tissues, hyperlastic tissues, and tissues in different stages of prostate cancer and to understand the effects of altered homeostasis of these elements in the origination of prostate cancer.

We have shown that the combination of element distribution patterns of prostate tissues with an appropriate statistical technique can be used as a useful tool for distinguishing normal tissues from various stages of cancer. The violin plots presented here synergistically combine box plots and the density trace into a single display that reveals structures found within the data. 
Table 1 The results of the Wilcoxon signed rank test

\begin{tabular}{|c|c|c|c|c|c|c|c|c|}
\hline & Hyperplastic & $P$ value & Gleason grade 2 & $P$ value & Gleason grade 3 & $P$ value & Gleason grade 4 & $P$ value \\
\hline \multirow[t]{4}{*}{ Healthy } & $\mathrm{Cu}$ & $<0.001$ & $\mathrm{Cu}$ & $<0.001$ & $\mathrm{Cu}$ & $<0.001$ & $\mathrm{Cu}$ & $<0.001$ \\
\hline & $\mathrm{Fe}$ & $>0.05$ & $\mathrm{Fe}$ & $<0.001$ & $\mathrm{Fe}$ & $<0.001$ & $\mathrm{Fe}$ & $<0.001$ \\
\hline & $\mathrm{Mn}$ & $>0.05$ & $\mathrm{Mn}$ & $<0.001$ & Mn & $<0.001$ & $\mathrm{Mn}$ & $<0.001$ \\
\hline & $\mathrm{Zn}$ & $<0.001$ & $\mathrm{Zn}$ & $<0.001$ & $\mathrm{Zn}$ & $<0.001$ & $\mathrm{Zn}$ & $<0.001$ \\
\hline \multirow[t]{4}{*}{ Hyperplastic } & & & $\mathrm{Cu}$ & $<0.001$ & $\mathrm{Cu}$ & $<0.001$ & $\mathrm{Cu}$ & $<0.001$ \\
\hline & & & $\mathrm{Fe}$ & $<0.001$ & $\mathrm{Fe}$ & $<0.001$ & $\mathrm{Fe}$ & $<0.001$ \\
\hline & & & $\mathrm{Mn}$ & $<0.001$ & $\mathrm{Mn}$ & $<0.001$ & $\mathrm{Mn}$ & $<0.001$ \\
\hline & & & $\mathrm{Zn}$ & $<0.001$ & $\mathrm{Zn}$ & $<0.01$ & $\mathrm{Zn}$ & $<0.05$ \\
\hline \multirow[t]{4}{*}{ Gleason grade 2} & & & & & $\mathrm{Cu}$ & $<0.001$ & $\mathrm{Cu}$ & $<0.001$ \\
\hline & & & & & $\mathrm{Fe}$ & $>0.05$ & $\mathrm{Fe}$ & $<0.001$ \\
\hline & & & & & $\mathrm{Mn}$ & $<0.001$ & $\mathrm{Mn}$ & $<0.001$ \\
\hline & & & & & $\mathrm{Zn}$ & $<0.001$ & $\mathrm{Zn}$ & $<0.001$ \\
\hline \multirow[t]{4}{*}{ Gleason grade 3} & & & & & & & $\mathrm{Cu}$ & $<0.001$ \\
\hline & & & & & & & $\mathrm{Fe}$ & $<0.001$ \\
\hline & & & & & & & $\mathrm{Mn}$ & $<0.001$ \\
\hline & & & & & & & $\mathrm{Zn}$ & $<0.001$ \\
\hline
\end{tabular}

The excess levels of $\mathrm{Mn}, \mathrm{Fe}, \mathrm{Cu}$, and $\mathrm{Zn}$ observed in the cancerous prostate tissues could be either a cause or a consequence of the pathological stages. Concerning the role of trace elements in the origination or advancement of prostate cancer, one possible surmise is that the raised levels of $\mathrm{Mn}, \mathrm{Fe}$, and $\mathrm{Cu}$ could have led to the formation of free radicals or other reactive oxygen species that adversely affect DNA, thereby causing prostate cancer. Additionally, because $\mathrm{Cu}$ and $\mathrm{Fe}$ are expected to initiate angiogenesis, elevated concentrations of these elements are likely to promote prostate cancer by increasing the blood supply for tumor growth. The elevated $\mathrm{Zn}$ concentrations observed in the present work may indicate that this element is required in neoplastic transformation and tumor growth.

On the other hand, elevated concentrations of elements in tissues in different stages of prostate cancer might also be a consequence of this disease. It is widely known that normal and cancerous tissues differ biochemically and histologically. Tumors, characterized by unregulated multiplication of cells, need an increasing supply of essential nutrients, including trace elements. This probably results in an increased vascularity of malignant tissues, which in turn leads to enhancement of elemental concentrations in tumors. The malignant process that has already started can result in a lowered concentration of microelements, which is shown in our studies for $\mathrm{Mn}, \mathrm{Cu}$, and $\mathrm{Zn}$ (Figs. 4, 6, 7) for all Gleason groups. The lowering of elemental content in tumorous tissue indicates the transport changes for some elements and a number of channels of the cell membrane.

The results obtained testify the promising nature of the study for understanding tissue degradation processes. The considerations relating to Gleason grading have called for the development of diagnostic tools that operate on the basis of cellular biochemical rather than visual tissue architectural recognition. Maybe manipulation of trace elements will provide new lines of treatment for cancers. It is clear that further studies with a larger number of tissue samples must be performed to consolidate the present conclusions. Moreover, the analysis and classification method presented in this work can be refined in the future, including the use of other types of tissues.

Acknowledgments This work was supported by HASYLAB, DESY, Hamburg (Germany), under project II-04-079EC and by IHPContract HPRI-CT-1999-00040/2001-00140 of the European Commission.

Open Access This article is distributed under the terms of the Creative Commons Attribution Noncommercial License which permits any noncommercial use, distribution, and reproduction in any medium, provided the original author(s) and source are credited.

\section{References}

1. Marks S (2003) Prostate and cancer: a family guide to diagnosis, treatment and survival. Perseus Publishing, Cambridge

2. Held-Warmkessel J (2005) Prostate cancer. In: Yarbro $\mathrm{CH}$, Frogge $\mathrm{MH}$, Goodman $\mathrm{M}$ (eds) Cancer nursing: principles and practice. Jones \& Bartlett, Sudbury, pp 1552-1580

3. Kirby RS, Brawer MK (2004) Prostate cancer. Health Press, Abington

4. Ramon J, Denis LJ (2007) Recent results in cancer research: prostate cancer. Springer, Berlin

5. Gleason DF (1977) In: Tannenbaum M (ed) Urologic pathology: the prostate. Lea and Febringer, Philadelphia, pp 171-197

6. Smith EB, Frierson HF, Millis SE, Boyd JC, Teodorscu D (2002) Cancer 94:2282-2287 
7. Lattouf JB, Saad F (2002) BJU Int 90:694-699

8. Epstein JI, Pizov G, Walsh PC (1993) Cancer 71:3582-3593

9. Naga Raju GJ, Sarita P, Ravi Kumar M, Ramana Murty GA, Seetharami Reddy B, Lakshminarayana S, Vijayan V, Rama Lakshmi PV, Satyanarayana G, Bhuloka Reddy S (2006) Nucl Instrum Methods Phys Res B 247:361-367

10. Geraki K, Farquharson MJ, Bradley DA (2002) Phys Med Biol 47:2327-2339

11. Geraki K, Farquharson MJ, Bradley DA (2004) Phys Med Biol 49:99-110

12. Geraki K, Farquharson MJ, Bradley DA, Hugtenburg RP (2004) Nucl Instrum Methods Phys Res B 213:564-568

13. Guntupalli JN, Padala S, Gummuluri AV, Muktineni RK, Byreddy SR, Sreerama L, Kedarisetti PC, Angalakuduru DP, Satti BR, Venkatathri V, Pullela VB, Gavarasana S (2007) Eur J Cancer Prev 16:108-115

14. Kwiatek WM, Banas A, Banas K, Gajda M, Galka M, Falkenberg G, Cichocki T (2005) J Alloy Compd 401:178-183

15. Kwiatek WM, Banas A, Gajda M, Galka M, Pawlicki B, Falkenberg G, Cichocki T (2005) J Alloy Compd 401:173-177

16. Leidenfrost JG (1966) Int J Heat Mass Transf 9:1153-1166

17. Chwiej J, Janeczko K, Marciszko M, Czyzycki M, Rickers K, Setkowicz Z (2010) J Biol Inorg Chem 15:283-289

18. Falkenberg G, Clauss O, Swiderski A, Tschentscher T (2001) X-ray Spectrom 30:170-173

19. Al-Ebraheem A, Farquharson MJ, Ryan E (2009) Appl Radiat Isot 67:470-474

20. Van Espen P, Janssens K, Swensters I (1989) AXIL X-ray analysis software users manual. Canberra Packard Benelux, Zellik

21. Kwiatek WM, Hanson AL, Paluszkiewicz C, Galka M, Gajda M, Cichocki T (2004) J Alloy Compd 362:83-87

22. Kwiatek WM (1999) Analiza fluorescencyjna. In: Hrynkiewicz AZ, Rokita E (eds) Fizyczne metody badan w biologii, medycynie i ochronie srodowiska. PWN, Warsaw, pp 366-406

23. R Development Core Team (2009) The R project for statistical computing. http://www.r-project.org

24. Altman DG (1991) Practical statistics for medical research. Chapman \& Hall/CRC, London

25. Hintze JL, Nelson RD (1998) Am Stat 52:181-184

26. Li H, Kantoff PW, Giovannucci E, Leitzmann MF, Gaziano JM, Stampfer MJ, Ma J (2005) Cancer Res 65:2498-2504

27. Szentmihalyi K, Vinkler P, Fodor J, Balla J, Lakatos B (2006) Orv Hetil 147:2027-2030

28. Erikson KM, Thompson K, Aschner J, Aschner M (2007) Pharmacol Ther 113:369-377

29. Machlin LJ, Bendich A (1987) FASEB J 1:441-445

30. Macmillan-Crow LA, Cruthirds DL (2001) Free Radic Res $34: 325-336$
31. Bothwell TH, Charlton RW, Cook JD, Finch CA (1979) Iron metabolism in man. Blackwell Scientific, Oxford

32. Andrews NC (1999) N Engl J Med 341:1986-1995

33. Salonen JT, Nyyssonen K, Korpela H, Tuomilehto J, Seppanen R, Salonen R (1992) Circulation 86:803-811

34. Tuomainen T, Punnonen K, Nyyssonen K, Salonen JT (1998) Circulation 97:1461-1466

35. Stevens RG, Jones DY, Micozzi MS, Taylor PR (1988) N Engl J Med 319:1047-1052

36. Salonen JT, Tuomainen TP, Nyyssonen K, Lakka H, Punnonen K (1998) BMJ 317:727-730

37. Walker EM Jr, Walker SM (2000) Ann Clin Lab Sci 30:354-366

38. Zowczak M, Iskra M, Paszkowski J, Manczak M, Torlinski L, Wysocka E (2001) J Trace Elem Med Biol 15:193-196

39. Rice-Evans C, Burdon R (1993) Prog Lipid Res 32:71-110

40. McCord JM (1998) Semin Hematol 35:5-12

41. Weinberg ED (1996) Eur J Cancer Prev 5:19-36

42. Toyokuni S (2009) Cancer Sci 100:9-16

43. Lieu PT, Heiskala M, Peterson PA, Yang Y (2001) Mol Aspects Med 22:1-87

44. Norrby K, Mattsby-Altzer I, Innocenti M, Tuneberg S (2001) Int J Cancer 91:236-240

45. Tappel A (2007) Med Hypotheses 68:562-564

46. Armendariz AD, Vulpe CD (2003) J Nutr 133:258E

47. Rae TD, Schmidt PJ, Pufahl RA, Culotta VC, O'Halloran TV (1999) Science 284:805-808

48. Folkman J (1990) J Natl Cancer Inst 82:4-6

49. Brem S (1999) Cancer Control 6:436-458

50. Hu G (1998) J Cell Biochem 69:326-335

51. Abdel-Mageed AB, Oehme FW (1990) Vet Hum Toxicol 32:34-39

52. Cousins RJ (1996) In: Ziegler EE, Filer LJ (eds) Present knowledge in nutrition. ILSI, Washington, pp 293-306

53. Wood RJ, Suter PM, Russell RM (1995) Am J Clin Nutr 62:493505

54. Shukla VK, Adukia TK, Singh SP, Mishra CP, Mishra RN (2003) J Surg Oncol 84:31-35

55. Beck FW, Kaplan J, Fine N, Handschu W, Prasad AS (1997) J Lab Clin Med 130:147-156

56. Gregoriadis GC, Apostolidis NS, Romanos AN, Paradellis TP (1983) Cancer 52:508-519

57. Margalioth EJ, Schenker JG, Chevion M (1983) Cancer 52:868872

58. Ho E, Song Y (2009) Curr Opin Clin Nutr Metab Care 12:640-645

59. Sapota A, Darago A, Taczalski J, Kilanowicz A (2009) Biometals 22:1041-1049

60. Rink L, Gabriel P (2001) Biometals 14:367-383

61. Rink L, Gabriel P (2000) Proc Nutr Soc 59:541-552

62. Ibs KH, Rink L (2003) J Nutr 133:1452S-1456S 